Peter Felten, ELON UNIVERSITY, pfelten@elon.edu Julianne Bagg, MCMASTER UNIVERSITY, baggjl@mcmaster.ca Michael Bumbry, LOYALA UNIVERSITY CHICAGO, mbumbry@luc.edu Jennifer Hill, UNIVERSITY OF THEWEST OF ENGLAND, Jennifer.Hill@uwe.ac.uk Karen Hornsby, NORTH CAROLINA A\&T STATE UNIVERSITY, kLhornsb@ncat.edu

\title{
A Call for Expanding Inclusive Student Engagement in SoTL
}

\section{ABSTRACT}

Scholars in higher education increasingly recognize the transformative potential of student-faculty partnerships focused on inquiry into teaching and learning. However, some students tend to be privileged in SoTL initiatives while others are discouraged, implicitly or explicitly, from engaging in this work. In this paper, we consider why certain students tend to be excluded from SoTL, summarize the possible developmental gains made by students and faculty when diverse student voices are included, and highlight strategies for generating a more inclusive SoTL. We call for expanding student engagement in SoTL by encouraging a diversity of student voices to engage in co-inquiry with faculty. Inclusive engagement has tremendous potential to enhance student and faculty learning, to deepen SoTL initiatives, and to help redress the exclusionary practices that too often occur in higher education.

\section{KEYWORDS}

SoTL, student engagement, inclusion, identity, student voice

\section{INTRODUCTION}

Educators are increasingly recognizing that engaging students actively in shaping their learning experiences can be transformative for both students and faculty (Kay, Dunne, \& Hutchinson, 2010). Partnerships in curriculum development, teaching, and the Scholarship of Teaching and Learning (SoTL) provide powerful opportunities for students and faculty to collaborate in the creation of new disciplinary, institutional, and pedagogic knowledge. Emerging evidence demonstrates that including students as partners in such work enhances student (as well as faculty) motivation, confidence and sense of intellectual agency, both within the immediate process and in wider academic settings (Bovill, Cook-Sather, \& Felten, 2011a; Cook-Sather, 2011; Mihans, Long, \& Felten, 2008). Student-faculty collaboration also "catalyzes a revision of students' relationships to their teachers and their responsibilities within their learning" (Cook-Sather \& Alter, 2011, p. 37), changing the nature of both the classroom and the inquiry process itself (Manor, Bloch-Schulman, Flannery, \& Felten, 2010). 
Partnering with students in SoTL, however, is not without challenges. Robinson (2012, p. 10) has argued that "an uncritical adoption of student engagement practices might reinforce existing hierarchies amongst the tutor-student and student-student relationships" to the extent that the "presence of institutional and social power relations can, therefore, lead to the silencing of some students' voices." At the same time, a society's exclusionary practices linked to gender, race, nationality, sexual orientation and socioeconomic status can be reconfigured in the academy to also silence certain voices. Because the SoTL literature rarely mentions socio-cultural or other demographics of student participants or partners (although see Cook-Sather \& Agu, 2013), scant evidence exists about how inclusive SoTL practices and inquiry actually are. Some scholars have suggested that certain students are privileged while others, particularly those lacking cultural capital in educational settings, are prone to be marginalized with respect to their participation in activities like SoTL (e.g. McIntyre, Pedder, \& Rudduck, 2005).

In this paper, we explore why some students may tend to be excluded from SoTL, the potential of intentionally including more diverse student voices in SoTL inquiries, and what opportunities exist for generating a more inclusive SoTL. We contend that widening the involvement of students as co-inquirers may contribute to enabling more transformative approaches to SoTL by:

1. Bringing new perspectives that reveal the routine conventions and assumptions that inform the questions we ask about teaching and learning;

2. Exploring and legitimizing ways of meaning making within SoTL inquiry that transgress the conventional methodologies of existing practice;

3. Reframing the ways that the outcomes of SoTL are communicated and, in doing so, recognizing students as a neglected group in SoTL dissemination practices (McKinney, 2012).

Throughout this paper, we will use brief examples from different campuses to illustrate the challenges and possibilities of a more inclusive SoTL.

\section{WIDENING STUDENT ENGAGEMENT IN SOTL}

In the United Kingdom (UK), Australia, Canada, and the United States, the concept of 'student voice' originated in the evolution of radical collegiality in primary and secondary schools, envisioning education as a genuine, demanding partnership between students and faculty (Fielding, 1999; Rudduck \& Flutter, 2004; Thomson \& Holdsworth, 2003). Analogous approaches have also emerged in different cultural contexts around the world (Kerr \& Keating, 2011). These ideas entered higher education in a variety of ways, often inspired by the writings of critical pedagogues like Paolo Freire (1970), or by programs such as the Carnegie Scholars and the Carnegie Academy for the Scholarship of Teaching and Learning (Hutchings, Huber, \& Ciccone, 2011). Across the spectrum of these movements, the focus on voice and engagement aims to empower students to take greater responsibility for their learning. At the simplest level, such initiatives afford learners an opportunity to share with faculty their views about the learning experience.

Deeper efforts encourage students to collaborate with faculty to effect change in their courses and institutions and, in rare cases, to assume leadership roles in this process (Kay et al., 2010). The ultimate aim, through reciprocal dialogue and participation, is to help transform education from the 'bottom up' through the co-construction of the learn- 
ing experience between students and faculty (Little, 2011; McCulloch, 2009). In SoTL, this may involve student participation through various approaches to inquiry into and experimentation with teaching and learning, such as course, curriculum and assessment design (Bovill et al., 2011a; Bovill, Bulley, \& Morss, 2011b; Delpish et al., 2010; Mihans et al., 2008; Neary \& Winn, 2009), students supporting one another through peer assisted learning and peer mentoring (Capstick \& Fleming, 2001; Donelan \& Kay, 1998), and students partnering with faculty as teaching and learning consultants (Cook-Sather, 2011; Cook-Sather, \& Alter, 2011).

In expanding student engagement in SoTL, both students and faculty must become accustomed to positions of liminality, confronting the "social roots of frameworks and beliefs about power and responsibility in the classroom and curriculum" (Cook-Sather \& Alter, 2011; Barnes, Goldring, Bestwick, \& Wood, 2010, p. 27). When traditional power hierarchies of higher education are scrutinized and destabilized, students may feel caught between their recognition of faculty authority and opportunities for more autonomous inquiry and action. Likewise, faculty may find themselves no longer the unquestioned experts, yet they will still hold significant power over students (Manor et al., 2010). A more equal faculty-student relationship is unfamiliar territory and its novelty and ambiguity often lead both parties to at least initial discomfort and uncertainty (Felten, 2011). Persistence in this liminal space, however, offers the possibility of challenging and disrupting established norms, promoting integration and inclusion rather than marginalization and exclusion of student voice.

Bringing multiple perspectives to bear on inquiry into teaching and learning practices can cause students and faculty to encounter dissonant, contested, and troublesome knowledge, provoking them to question their assumptions. Such deeper questioning may lead to crossing thresholds of understanding, which allow fundamentally new ways of thinking that cannot be undone (Meyer, Land, \& Bailie, 2010). These changes are not limited to students; when faculty and students partner on inquiries into teaching and learning, both groups expand their pedagogical intelligence (Hutchings, 2005). This metacognitive orientation enhances both student learning and faculty teaching (Werder \& Otis, 2010). For the development of both to be maximized, the full range of student voices should be engaged to create the richest dialogue possible about the learning experience.

Integrating and honoring the diversity of student perspectives, however, is no simple task. Involving students as key participants in the quality assurance and enhancement of their university experience, for example, has become common in the UK where the foregrounding of the student empowerment agenda parallels funding reform and a rise in student fees. Indeed, the UK Quality Assurance Agency has recently enshrined student engagement within the quality code for higher education (QAA, 2012). Yet this "sacralisation" of the discourse of the "student experience" at a time of fundamental change within the system has led some to question the legitimacy of promoting student engagement at all levels of the university. Specifically, some argue that the advocacy of the individual within the collective student experience in reality works to homogenize students and deprive them of agency in real terms (Sabri, 2011). In addition, McLeod (2011) notes that it is often difficult to attend to the inter-sectionalities within student voice work since social identities such as race, gender and sexual orientation do not exist in isolation but intersect simultaneously. One aspect of voice (such as gendered voice) may silence differences in the same dialogue (such as socioeconomic class), creating a false sense of common- 
ality. Therefore, within the work to promote student engagement in SoTL we must avoid characterizing voice to simplified, singular and stable typologies (Cook-Sather, 2007). Knowing which voices are included, excluded or silenced in SoTL work, thus, is a central concern for anyone engaged in or applying the results of SoTL inquiries.

\section{WHY MIGHT SOME STUDENT VOICES BE EXCLUDED?}

Patterns of inclusion and exclusion in higher education vary across the globe. In different cultural, regional, and institutional contexts, some students are more likely to be underrepresented and marginalized. For example, at predominantly white institutions in the United States, students of color may find it difficult to get involved in campus activities (Harper, 2009; Harper, \& Quaye, 2009). This lack of campus engagement may impact students' sense of belonging at the institution (Cole, 2007). As a result, they may be less likely to collaborate with faculty in SoTL because of a perceived lack of support from faculty or their own self-efficacy about their capacity to excel as co-researchers. Many other factors, including socio-economic status and sexual orientation, also are important to consider as these are additional barriers that many students encounter aside from the general challenges of being a college student (Sacks, 2007). Even one's academic major may have an impact on an individual's propensity to engage in SoTL inquiry due to degree requirements.

Beyond those broad factors, common faculty and institutional practices may further limit the range of students who engage in SoTL. For example, the methods typically used for selecting SoTL student co-researchers often influence which voices are heard. Two common selection practices are open enrollment into classes and faculty inviting individual students to partner in research. At North Carolina Central University (Wymer, Fulford, Baskerville, \& Washington, 2012) and Western Carolina University (Ingram, 2012), for instance, students enrolled in specific courses conduct SoTL research. This approach typically restricts SoTL participation to students with a particular standing in a major, the good fortune of being taught by the inquiring faculty member, or with sufficient room in their schedule to take a non-required course. In comparison, to make it as easy as possible for all students to engage in SoTL, Western Washington University's Teaching and Learning Academy (TLA) functions as an open-enrollment course without prerequisites or class standing requirements. However, even in this case, students from departments that are physically distant from the TLA meeting space rarely participate (C. Werder, personal communication, October 26, 2012).

Another practice that may exclude some students is the faculty practice of selecting academically strong students for co-inquiry projects. In Eastern Michigan University's collaborative inquiry SoTL project, for example, Jeffrey Bernstein selected students with "strong GPAs and a track record of academic achievement" (Gutman, Sergison, Martin, \& Bernstein, 2010, p. 134). This intentional selection process was based on the level of expertise needed for students to facilitate simulations in this research. At Elon University, student course-redesign partners were selected through an application process (Mihans et al., 2008), while University College Dublin selected student co-creators for a geography curriculum through a job advertisement (Bovill et al., 2011a). Although none of these selection methods is inherently disenfranchising to particular students (and each presumably is designed to enhance the quality of the SoTL inquiry), these practices might unintentionally be narrowing the range of students who might make valuable contribu- 
tions to the research. To foster less singularity of student voice, SoTL practitioners might take active steps to diversify marketing, recruitment and selection methods.

Faculty assumptions about students may reinforce these exclusionary practices. A study by Popovic and Green (2012) into UK and US university teachers' beliefs about common qualities of successful students revealed some erroneous but broadly held preconceptions. Faculty in both countries tend to presume that successful students belong to a particular ethnic group (white in most cases), regularly ask questions and converse with teachers about course material, and are of a particular gender (with differences contingent on subject). Additionally, UK teachers commonly but inaccurately believe that good students attend the university full-time while US educators typically perceive that successful undergraduates are not athletes, not married, and speak English at home. Although faculty may not openly share or even be aware of these beliefs, such preconceptions might influence which students are invited to partner in SoTL research.

Institutional practices also contribute to silencing some student voices in SoTL. For instance, the design of undergraduate research programs shape, sometimes unintentionally, who is able to participate. For example, Angelo State University (ASU) in Texas recently created an Undergraduate Research Initiative open to all students. The program provides a modest monetary grant but expects students to "make a major commitment of time and effort." Although ASU is a Hispanic Serving Institution, white male science majors have been the largest group of participants in this program. Restructuring this program by making it more accessible to students who need to financially support themselves while in college would likely diversify student participation, bringing more student voices into the research and SoTL conversations across campus (J. Wegner, personal communication, October 24, 2012). SoTL practitioners would be wise to consider institutional factors that might be contributing to any participation gap among marginalized students.

Beyond general efforts to reach all students, certain classes of undergraduates such as non-traditional, single parent, military and student athlete learners may require special institutional accommodations for inclusion of their voices in SoTL research (HintonSmith, 2012). Particularly when an increase in the student-researcher's role or the complexity of inquiry necessitates greater student-faculty contact, undergraduates with significant commitments outside of curricular obligations (e.g., child care, work, practice, etc.) may require additional planning on the part of the students and faculty involved (Stevenson \& Clegg, 2012).

Despite the difficulties, some initiatives are finding success in engaging a wide range of students in SoTL inquiry. For example, the Students as Learners and Teachers program at Bryn Mawr College in Pennsylvania deliberately selects underrepresented students on campus to serve as pedagogic consultants to faculty members. Many of these are students of color and/or international students, bringing often unheard voices into teaching dialogues in a majority-white and US institutional context (Cook-Sather \& Agu, 2013). Similarly, the Wabash-Provost Scholars program at North Carolina A\&T State University intentionally recruited across campus to bring diverse voices into a project concerned with analyzing the institution's assessment data (Baker, 2012). While each of these programs relies on careful action and local context, taken together they demonstrate the possibility of SoTL projects to connect with students who often are on the physical, social, and intellectual peripheries of our campuses. 


\section{OPPORTUNITIES FOR CREATING A MORE INCLUSIVE SOTL}

While these individual programs highlight the potential for more inclusive SoTL practice, three approaches hold significant promise for systematically expanding student engagement with this inquiry: engaging students in relatively flexible places on campus, educating students about the purposes and practices of SoTL, and helping develop the academic skills necessary for students to participate in serious inquiry into learning and teaching.

Starting on the margins of our campuses is one strategy for creating more inclusive SoTL practices. This inquiry might begin in some of the more fluid moments on our campuses, including the ways we orient new students to the university, the variety of informal personal interactions that occur between students and faculty, and the times we reach off campus with students in fieldwork or community-based projects. Online tools might offer additional spaces where roles are less well defined or understood (Glasser \& Powers, 2011), helping to dissolve existing power asymmetries of the traditional classroom and to encourage expression of diverse identities and voices - creating what Savin-Baden (2008, p. 32) calls "spaces for meddling with" the often unquestioned privileging of particular knowledge and experiences over others in higher education. Not only are these sometimes marginal spaces perhaps more open to questioning and challenge, they also are spaces where faculty can find ready student partners who might be marginalized in other aspects of the university experience. By developing practices and habits of inquiry with students in these peripheral spaces, we might develop the capacity to introduce student-faculty SoTL inquiry to the more formal core of our campuses, including traditional classrooms and curricula, in ways that are transformational for the methodological and pedagogical potential of SoTL.

Another approach to encouraging the inclusion of all student voices in SoTL is through education and awareness (Winkelmes \& Mustari, 2013). Students (and indeed some academic staff) cannot be expected to participate in SoTL research and inquiry if they have no sound concept of what the practice entails. Moreover, new undergraduate students are likely to disregard any calls for participation if they do not understand the expectations and purpose of such an engagement. Hence, all students need to be informed of what SoTL is and about the opportunities that exist for involvement in such inquiries. This suggestion does not assume all students will want to, or must, participate in SoTL but that they are all given equal access to such opportunities to choose when and how to participate (Barnes et al., 2010). Additionally, students need to learn about the potential benefits that can result from participating in SoTL research. Reflective practice is a teaching strategy that a teacher may employ within the curriculum to encourage students to critique their learning experience and identify areas for growth. Teaching students how to provide useful feedback is also a good way to promote the development of their voices and personal growth (Trask, Maritz-Baden, Settles, Gentry, \& Burke, 2009), hence increasing their confidence to engage in SoTL initiatives.

A further way to enhance the inclusion of students in SoTL is to help students develop effective communication and research skills in many courses. While some students are already able to communicate their ideas in verbal and written forms prior to enrolling in higher education, asking critical questions in an academic setting may initially prove 
challenging for some students (Turner, 2013). Courses involving effective oral communication, intensive writing, information literacy and principles of the research process can help students to cultivate the capacities necessary to engage in SoTL - and also that will enhance their overall academic and professional development (Kuh, 2008). Using assignments that apply elements of the research process, developing outlines, writing literature reviews and grants, and presenting at conferences can assist in this process (Healey, 2005). This approach not only meets many of our core academic goals for students, but it will also prepare more students to be ready to inquire with us into learning and teaching.

\section{INCLUSIVE APPROACHES TO COMMUNICATING THE OUTCOMES OF SOTL}

Integrating diverse voices into SoTL has the potential to challenge existing inquiry practices and assumptions, to open up new research methodologies and approaches to meaning making, and to engage with new audiences for this work. Current SoTL practice follows conventional scholarly habits, particularly as we go public with our findings in peer-reviewed publications and paper presentations at professional conferences. While these traditional formats can exclude or marginalize student voices, prominent SoTL scholars remind us that other legitimate forms of sharing our work, such as online portfolios (Bernstein \& Bass, 2005), or even informal networks of colleagues (Huber, 2009), are appropriate for many inquiries. We support these calls for an evolution towards a greater diversity of formats for going public with SoTL, such that students are able to access, share and develop this work (McKinney, 2012). Engaging in SoTL might offer opportunities for faculty and students to communicate their findings to one another through a range of formats that are more accessible to the latter, including websites, blogs, exhibitions, and video and audio podcasts.

By sharing our SoTL practices and results in ways that engage a wider range of students and faculty, we can stimulate deeper and broader inquiry into learning and teaching. This can transform the university experience rather than reify existing academic practices that privilege certain ways of knowing and being. Intentionally broadening the range of student voices in SoTL will enable us to ask additional and different questions, and to pursue new lines of inquiry and dissemination. In doing so, we resist the potential that, whilst SoTL gains a valid status in the academy, drawing on a limited range of student voices can inadvertently sustain narrow definitions of legitimate student identities and promulgate culturally-bound conceptions of what student engagement can look like. While doing this is hard—any countercultural work takes time and effort—engaging in more inclusive SoTL will encourage fundamental "cultural shifts that support a repositioning of students" on campuses, in classrooms, and in educational research and reform (Cook-Sather, 2011, p. 361). Legitimizing a multiplicity of voices and experiences in SoTL, and ensuring the outcomes of SoTL are communicated to and with students to the academic community as a whole will enable all students to feel increasingly able to be actively and creatively involved in understanding and transforming the relations between 'faculty' and 'student', as mutual co-creators of disciplinary and pedagogic knowledge in their curricula. This shift will allow students to engage further with, and progress beyond, their disciplinary identities (Chick, 2013), to express their complex and intersecting personalities, and to trust their judgement in order to make informed decisions in and beyond the academy. 


\section{CONCLUSION}

In this paper, we have argued for a revisiting of the terms and practices of SoTL to take further account of students who are traditionally included and excluded in inquiry as co-learners and co-researchers with faculty. As student engagement in SoTL is being increasingly adopted to ensure that the outcomes of inquiry reflect the experiences, questions, and concerns of students, it is timely to ensure that such practices are not deliberately or unconsciously excluding voices and identities that do not align with the traditional structures of higher education and scholarship. Examining our practices in terms of who participates, what their role is in shaping SoTL inquiry, and how the outcomes of that inquiry are disseminated is essential to ensure that all students are afforded legitimate agency in shaping their own education and understanding that of others. Such reflexive scrutiny should encourage a liberatory education for both students and faculty.

Julianne Bagg, HBSc, is a recent graduate of the Honours Integrated Science program at McMaster University, Hamilton, Canada.

Michael Bumbry, M.Ed., is a Ph.D. student in the Higher Education Administration program at Loyola University Chicago, USA.

Peter Felten, PhD, is Assistant Provost, Director of the Center for Engaged Learning and the Center for the Advancement of Teaching \& Learning at Elon University, North Carolina, USA.

Jennifer Hill, PhD, is Associate Professor in Teaching and Learning at the University of the West of England, Bristol, UK.

Karen Hornsby, PhD, is an Associate Professor of Philosophy at North Carolina A\&T State University in Greensboro, North Carolina, USA.

Maria Pratt, RN, is a PhD student and Nursing Instructor at McMaster University in Hamilton, Canada.

Saranne Weller, PhD, is Assistant Director and Senior Lecturer in Higher Education in King's Learning Institute at King's College London, UK.

\section{REFERENCES}

Baker, G. R. (2012, February). North Carolina A\&T State University: A culture of inquiry. National Institute for Learning Outcomes Examples of Good Assessment Practice. Urbana, IL: University of Illinois and Indiana University.

Barnes, E., Goldring, L., Bestwick, A. \& Wood, J. (2010). A collaborative evaluation of studentstaff partnership in inquiry-based educational development. In S. Little (Ed.), Staff-student partnerships in higher education (pp. 16-30). London: Continuum.

Bernstein, D., \& Bass, R. (2005). The scholarship of teaching and learning. Academe: Journal of Leadership and Management in Higher Education, 91(4), 37-43.

Bovill, C., Bulley, C. J., \& Morss, K. (2011b). Engaging and empowering first-year students through curriculum design: Perspectives from the literature. Teaching in Higher Education, 2, 197-209. doi 10.1080/13562517.2010.515024 
Bovill, C., Cook-Sather, A., \& Felten, P. (2011a). Students as co-creators of teaching approaches, course design, and curricula: Implications for academic developers. International Journal for Academic Development, 16, 133-145. doi 10.1080/1360144X.2011.568690

Capstick, S., \& Fleming, H. (2001). Peer assisted learning in an undergraduate hospitality course: Second year students supporting first year students in group learning. Journal of Hospitality, Leisure, Sport \& Tourism Education, 1, 69-75.

Chick, N. L. (2013). Difference, privilege and power in the scholarship of teaching and learning: The value of the humanities in SoTL. In K. McKinney (Ed.), The scholarship of teaching and learning in and across the disciplines (pp. 15-33). Indiana: Indiana University Press.

Cole, D. (2007). Do interracial interactions matter? An examination of student-faculty contact and intellectual self-concept. Journal of Higher Education, 27(3), 249-281.

Cook-Sather, A. (2007). Resisting the impositional potential of student voice work: Lessons for liberatory educational research from poststructuralist feminist critiques of critical pedagogy. Discourse: Studies in the Cultural Politics of Education, 28, 389-403.

Cook-Sather, A. (2011). Layered learning: Student consultants deepening classroom and life lessons. Educational Action Research, 19, 41-57.

Cook-Sather, A., \& Agu, P. (2013). Students of Color and Faculty Members Working Together Toward Culturally Sustaining Pedagogy. In Groccia, J., \& Cruz, L. (Eds.), To Improve the Academy, 32. San Francisco: Jossey. Bass/Anker.

Cook-Sather, A. \& Alter, Z. (2011). What is and what can be: How a liminal position can change learning and teaching in higher education. Anthropology and Education Quarterly, 42, 3753. doi: 10.1111/j.1548-1492.2010.01109.x

Delpish, A., Darby, A., Holmes, A., Knight-McKenna, M., Mihans, R., King, C., \& Felten, P. (2010). Equalizing voices: Student-faculty partnership in course design. In C. Werder \& M. Otis (Eds.), Engaging student voices in the study of teaching and learning (pp. 96-114). Sterling, VA: Stylus.

Donelan, M., \& Kay, P. (1998). Supplemental instruction: Students helping students' learning at University College London (UCL) and University of Central Lancashire (UCLAN). International Journal of Legal Education, 32, 287-299.

Felten, P. (2011, Winter). Monet moments and the necessity of productive disruption. Teaching and Learning Together in Higher Education, 2. Retrieved from http://teachingandlearningto gether.blogs.brynmawr.edu/archived-issues/spring2011-issue/from-the-advisory-board

Fielding, M. (1999). Radical collegiality: Affirming teaching as an inclusive professional practice. Australian Educational Researcher: A Publication of the Australian Association for Research in Education, 26, 1-34.

Freire, P. (1970). Pedagogy of the oppressed. New York: Herder and Herder.

Glasser, H. M., \& Powers, M. A. (2011). Disrupting traditional student/faculty roles, 140 characters at a time. Teaching and Learning Together in Higher Education, February. Retrieved from http://teachingandlearningtogether.blogs.brynmawr.edu/archived-issues/spring2011 -issue/disrupting-traditional-roles

Gutman, E. M., Sergison, E. M., Martin, C. J., \& Bernstein, J. L. (2010). Engaging students as 
scholars of teaching and learning. In C. Werder \& M. M. Otis (Eds.), Engaging student voices in the study of teaching and learning (pp. 130-145). Sterling, VA: Stylus Publishing.

Harper, S. R. (2009). Institutional seriousness concerning black male student engagement: Necessary conditions and collaborative partnerships. In S. R. Harper \& S. J. Quaye (Eds.), Student engagement in higher education: Theoretical perspectives and practical approaches for diverse populations (pp. 137-156). New York: Routledge.

Harper, S. R., \& Quaye, J. (2009). Beyond sameness, with engagement and outcomes for all. In S. R. Harper \& S. J. Quaye (Eds.), Student engagement in higher education: Theoretical perspectives and practical approaches for diverse populations (pp. 1-15). New York: Routledge.

Healey, M. (2005). Linking research and teaching to benefit student learning. Journal of Geography in Higher Education, 29(2), 183-201.

Hinton-Smith, T. (Ed) (2012). Widening participation in higher education: Casting the net wide? Basingstoke, Hampshire: Palgrave Macmillan.

Huber, M. T. (2009). Teaching travels: Reflections on the social life of classroom inquiry and innovation. International Journal for the Scholarship of Teaching and Learning 3(2).

Hutchings, P. (2005). Building pedagogical intelligence. Carnegie Perspectives. Retrieved from: http://www.carnegiefoundation.org/perspectives/building-pedagogical-intelligence

Hutchings, P., Huber, M.T., \& Ciccone, T. (2011). The scholarship of teaching and learning reconsidered: Institutional integration and impact. San Francisco, CA: Jossey-Bass.

Ingram, J. (2012, September 4). Student-led assessment sheds light on retention. The Reporter: Western Carolina University Faculty \& Staff News. Retrieved from http://thereporter .wcu.edu/2012/09/student-led-assessment-sheds-light-on-retention/

Kay, J., Dunne, E., \& Hutchinson, J. (2010). Rethinking the values of higher education - students as change agents? Gloucester: QAA. Retrieved from: www.qaa.ac.uk/students /studentengagement/undergradaute.pdf

Kerr, D. \& Keating, A. (2011). Intercultural, citizenship and human rights education: The challenges of implementation for policy, practice and research. Educational Research, 53(2), 119-122.

Kuh, G. (2008). High-impact educational practices: What they are, who has access to them, and why they matter. Washington, DC: Association of American Colleges and University.

Little, S. (Ed.) (2011). Staff-student partnerships in higher education. London: Continuum.

Manor, C., Bloch-Schulman, S., Flannery, K., \& Felten, P. (2010). Foundations of student-faculty partnerships in the scholarship of teaching and learning: Theoretical and developmental considerations. In C. Werder \& M. Otis (Eds.), Engaging student voices in the study of teaching and learning (pp. 81-95). Sterling, VA: Stylus.

McCulloch, A. (2009). The student as co-producer: Learning from public administration about the student-university relationship. Studies in Higher Education, 34(2), 171-183.

McIntyre, D., Pedder, D., \& Rudduck, J. (2005). Pupil voice: Comfortable and uncomfortable learning for teachers. Research Papers in Education, 20, 149-168.

McKinney, K. (2012). Increasing the impact of SoTL: Two sometimes neglected opportu- 
nities. International Journal for the Scholarship of Teaching and Learning, 6(1). Retrieved from http://dspaceprod.georgiasouthern.edu:8080/jspui/bitstream/10518/4882/1/IJ-SoTL _v6n1_IE_McKinney.pdf

McLeod, J. (2011). Student voice and the politics of listening in higher education. Critical Studies in Education, 52, 179-189.

Meyer, J. H. F., Land, R., \& Bailie, C. (Eds.). (2010). Threshold concepts and transformational learning. Boston, MA: Sense Publishers.

Mihans, R., Long, D., \& Felten, P. (2008). Power and expertise: Student-faculty collaboration in course design and the scholarship of teaching and learning. International Journal for the Scholarship of Teaching and Learning, 2, 1-9.

Neary, M., \&Winn, J. (2009). Student as producer: Reinventing the undergraduate curriculum. In M. Neary, H. Stevenson, and L. Bell (Eds.) The future of higher education: Policy, pedagogy and the student experience (pp. 192-210). London: Continuum.

Popovic, C., \& Green, D. A. (2012) Understanding undergraduates: Challenging our preconceptions of student success. New York, NY: Routledge.

Quality Assurance Agency (QAA). (2012). UK quality code for higher education. Gloucester: The Quality Assurance Agency.

Robinson, C. (2012). Student engagement: What does this mean in practice in the context of higher education institutions? Journal of Applied Research in Higher Education, 4, 94-108.

Rudduck, J., \& Flutter, J. (2004). How to improve your school: Giving pupils a voice. London: Continuum Press.

Sabri, D. (2011). What's wrong with the'student experience'?, Discourse: Studies in the Cultural Politics of Education, 32(5), 657-667.

Sacks,P. (2007). Tearing down the gates: Confronting the class divide in American education. Berkeley, CA: University of California Press.

Savin-Baden, M. (2008). Learning spaces: Creating opportunities for knowledge creation in academic life. Maidenhead: Open University Press.

Stevenson, J., \& Clegg, S. (2012). Who cares? Gender dynamics in the valuing of extra-curricular activities in higher education. Gender and Education, 24, 41-55.

Thomson, P., \& Holdsworth, R. (2003). Theorizing change in the educational 'field': Rereadings of 'student participation' projects. International Journal of Leadership in Education, 6, 371-391.

Trask, B.S., Maritz-Baden, R., Settles, B., Gentry, D., \& Burke, D. (2009). Enhancing graduate education: Promoting a scholarship of teaching and learning through mentoring. International Journal of Teaching and Learning in Higher Education, 20, 438-446.

Turner, Y. (2013) Pathologies of silence? Reflecting on international learner identities amidst the classroom chatter. In J. Ryan (Ed.) Cross-cultural teaching and learning for home and international students: Internationalisation of pedagogy and curriculum in higher education (pp. 227-240). London: Routledge.

Werder, C., \& Otis, M., eds. (2010). Engaging student voices in the study of teaching and learning. Sterling, VA: Stylus. 
Winkelmes, M-A., \& Mustari, E. (2013, Spring). Empowering faculty to improve students' learning through collaborative assessment. Liberal Education, 99:2.

Wymer, K., Fulford, C., Baskerville, N., \& Washington, M. (2012). Necessity and the unexpected: SoTL student-faculty collaboration in writing program research. International Journal for the Scholarship of Teaching and Learning, 6(1), Retrieved from http://academics .georgiasouthern.edu/ijsotl/v6n1/essays_about_sotl/PDFs/Wymer\%20et\%20al \%20revised.pdf. 